\title{
Effects of habitat on spillover from marine protected areas to artisanal fisheries
}

\author{
Aitor Forcada ${ }^{1, *}$, Carlos Valle ${ }^{1}$, Patrick Bonhomme ${ }^{2}$, Géraldine Criquet $^{3}$, \\ Gwenaël Cadiou $^{2}$, Philippe Lenfant ${ }^{3}$, José L. Sánchez-Lizaso ${ }^{1}$ \\ ${ }^{1}$ Unidad de Biología Marina, Departamento de Ciencias del Mar y Biología Aplicada, Universidad de Alicante, POB 99, \\ 03080 Alicante, Spain \\ ${ }^{2}$ GIS Posidonie, Parc Scientifique \& Technologique de Luminy, Case 901, 13288 Marseille Cedex 09, France \\ ${ }^{3}$ Laboratoire Ecosystèmes Aquatiques Tropicaux et Méditerranéens, UMR 5244 CNRS-EPHE-UPVD ‘Biologie et Ecologie \\ Tropicale et Méditerranéenne', Université de Perpignan, 52 avenue Paul Alduy, 66860 Perpignan Cedex, France
}

\begin{abstract}
Marine protected areas (MPAs) potentially enhance the long-term sustainability of coastal fish resources that have been overexploited. The types and quality of habitats, both inside and outside the MPAs, may determine the likelihood of migration by fish to surrounding unprotected areas where spillover to fisheries occurs. We assessed whether MPAs enhanced catches of artisanal fisheries, using an experimental fishing study with the same fishing gear as that used by local fishers. This approach allowed us to test the hypothesis of increased catches along the borders of MPAs in comparison with those in other fishing grounds located at medium and far distances from 3 Mediterranean MPAs: Tabarca Marine Reserve, Carry-le-Rouet Marine Reserve and Cerbère-Banyuls Marine Reserve. Surveys were done over 2 homogeneous habitats (Posidonia oceanica meadow and sand), in 3 different seasons. Catches were significantly higher for some species near the borders of the MPAs when fishing on $P$. oceanica meadows, but not when fishing on sandy bottoms. The spillover effect appears to be limited by a lack of continuous suitable habitat through the boundaries of the MPA. Some of the species that showed a significant response to protection and concurrent higher catches near the MPA borders, such as Dentex dentex, Mullus surmuletus, Phycis phycis, Sciaena umbra and Scorpaena porcus, are target species of artisanal fisheries. Although we found that the spatial scale of the spillover-induced density gradient was localized, it was sufficient to provide local benefits to artisanal fisheries. We conclude that spillover effects are not a universal consequence of siting MPAs in temperate waters and that they are related to the distribution of habitats inside and around MPAs.
\end{abstract}

KEY WORDS: MPA · Export production · Artisanal fisheries · Fish · Habitat connectivity $\cdot$ Spillover · Mediterranean Sea

Resale or republication not permitted without written consent of the publisher

\section{INTRODUCTION}

In recent years, many coastal fish resources have been overexploited (Castilla 2000), raising doubts about the long-term sustainability of certain fisheries (Pauly et al. 2002). Unless changes are implemented immediately, many fisheries may collapse in the next few decades (Worm et al. 2006). The solutions proposed by managers for this critical problem are numerous (Pauly et al. 2002) and rely on: (1) reducing fishing capacity through 'traditional' fisheries measures (e.g. quotas, reducing fishing effort, regulating fishing equipment); and (2) creating marine protected areas (MPAs). The first option has not always provided the anticipated effects, leading many to adopt MPAs as a fishery management strategy (Roberts et al. 2003).

MPAs potentially facilitate the long-term sustainability of many fisheries (Gell \& Roberts 2003, RamosEsplá et al. 2004). Closing areas allows animals to live longer and grow to maturity, which is important for 
supporting fisheries because of the exponential relationship between fecundity and body size (Bohnsack 1990). MPAs are predicted to benefit adjacent fisheries through 2 mechanisms: (1) net emigration of adults and juveniles across borders, termed 'spillover'; and (2) increased production and export of pelagic eggs and larvae (Gell \& Roberts 2003, Kaunda-Arara \& Rose 2004, Abesamis \& Russ 2005, Sale et al. 2005). Spillover of juvenile and adult fish to surrounding non-protected areas could result from random movements of individuals from MPAs to outside their borders or by directed movements over a large home range (Rakitin \& Kramer 1996, Kramer \& Chapman 1999, Tremain et al. 2004). Emigration may also occur through ontogenetic habitat shifts (Cocheret de la Moriniere et al. 2002, Nagelkerken \& van der Velde 2002). All these cases are considered density-independent movements. Another mechanism that could lead to export is the occurrence of density-dependent movements of competitively subordinate individuals from preferred habitats inside MPAs to suboptimal habitats outside (Sánchez-Lizaso et al. 2000, Abesamis \& Russ 2005). Both densityindependent and density-dependent processes would produce a gradient of abundance across MPAs borders and should have an influence on the yields and quality of the catches in the surrounding fishing grounds (Russ \& Alcala 1996, Gell \& Roberts 2003). However, the patchy nature of the marine environment might act as a barrier for the movement of fish, although habitat discontinuities might not be perceived in the same manner by all animals (Wiens et al. 1993). Many fishes are habitat specific and are reluctant to disperse across 'foreign' habitats (Chapman \& Kramer 2000). For this reason, spillover will also be influenced by the habitat bordering a reserve (Rowley 1994).

Some of the best evidence for spillover comes from landings data that have demonstrated increased captures in fisheries adjacent to MPAs in many parts of the world: Kenya (McClanahan \& Kaunda-Arara 1996, McClanahan \& Mangi 2000), Florida and St Lucia (Roberts et al. 2001a), New England (Murawski et al. 2000, 2005), the Egyptian Red Sea (Galal et al. 2002) and Apo Island in the Philippines (Russ et al. 2003). However, only a few studies have experimentally tested for spillover through increased captures in adjacent fished areas, often along density gradients: Barbados (Rakitin \& Kramer 1996), Kenya (McClanahan \& Mangi 2000, Kaunda-Arara \& Rose 2004) and Apo Island in the Philippines (Abesamis \& Russ 2005). In the Mediterranean, few data are available to assess the value of MPAs as a source of biomass to surrounding fisheries (Goñi et al. 2006).

Encouraged by the recent findings on spillover results, many countries and states have started initiatives to establish networks of marine reserves. However, too little evidence exists to define the basic responses of fish populations to reserve protection (Willis et al. 2003) and their potential for improving fisheries yields (Hilborn et al. 2004). Moreover, reserves remain highly controversial among fishers and the fishing industry, who argue that fishery benefits remain unproven.

Protection of breeding stock, enhancement of recruitment to neighbouring areas, and restocking of exploited marine species were the initial goals of the 3 Mediterranean MPAs studied here. The main objective of this work was to estimate fisheries enhancement around these MPAs and to assess the influence of habitat on this process. We adopted an experimental fishing approach with commercial trammel nets, the most common fishing gear used in Mediterranean artisanal fisheries. This approach allows for testing the hypothesis that catches will be increased along the border of MPAs in comparison with other fishing grounds. We incorporated 2 habitats in the present study (Posidonia oceanica seagrass meadow and sandy bottom), with the aim of testing whether habitat type alters the degree of spillover from MPAs.

\section{MATERIALS AND METHODS}

Study area. This study was conducted July 2003 to June 2005 in 3 MPAs in the western Mediterranean Sea, off the coasts of Spain and France, encompassing a geographic range $>1000 \mathrm{~km}$ (Fig. 1). Tabarca Marine Reserve covers $1400 \mathrm{ha}$, and is substantially larger than Cerbère-Banyuls Marine Reserve (650 ha) and Carry-le-Rouet Marine Reserve (85 ha). Tabarca Marine Reserve, which is only $4 \mathrm{~km}$ from the mainland, contains 3 management zones with different levels of protection: the integral reserve area, where all activities except scientific research are forbidden; the buffer area, in which selective artisanal fishing gear (trap nets that target on pelagic species) is allowed; and the transitional area, in which the prior selective fishing gear and recreational activities (swimming, diving, mooring of yachts) are permitted. However, the entire marine reserve acts as a no-take-zone for the species targeted by trammel nets, because this gear is banned inside the MPA. Cerbère-Banyuls Marine Reserve has 2 management zones: the integral reserve, where all activities except scientific surveys are forbidden, and the restricted use area, in which commercial and recreational fishing, swimming and diving activities are regulated and spear fishing is forbidden. In contrast, the Carry-le-Rouet Marine Reserve has no zoning and is entirely a no-take marine reserve.

The 3 MPAs have all been established for at least $20 \mathrm{yr}$, and they have yielded evidence of higher biomass within their borders. Overall fish abundance was 

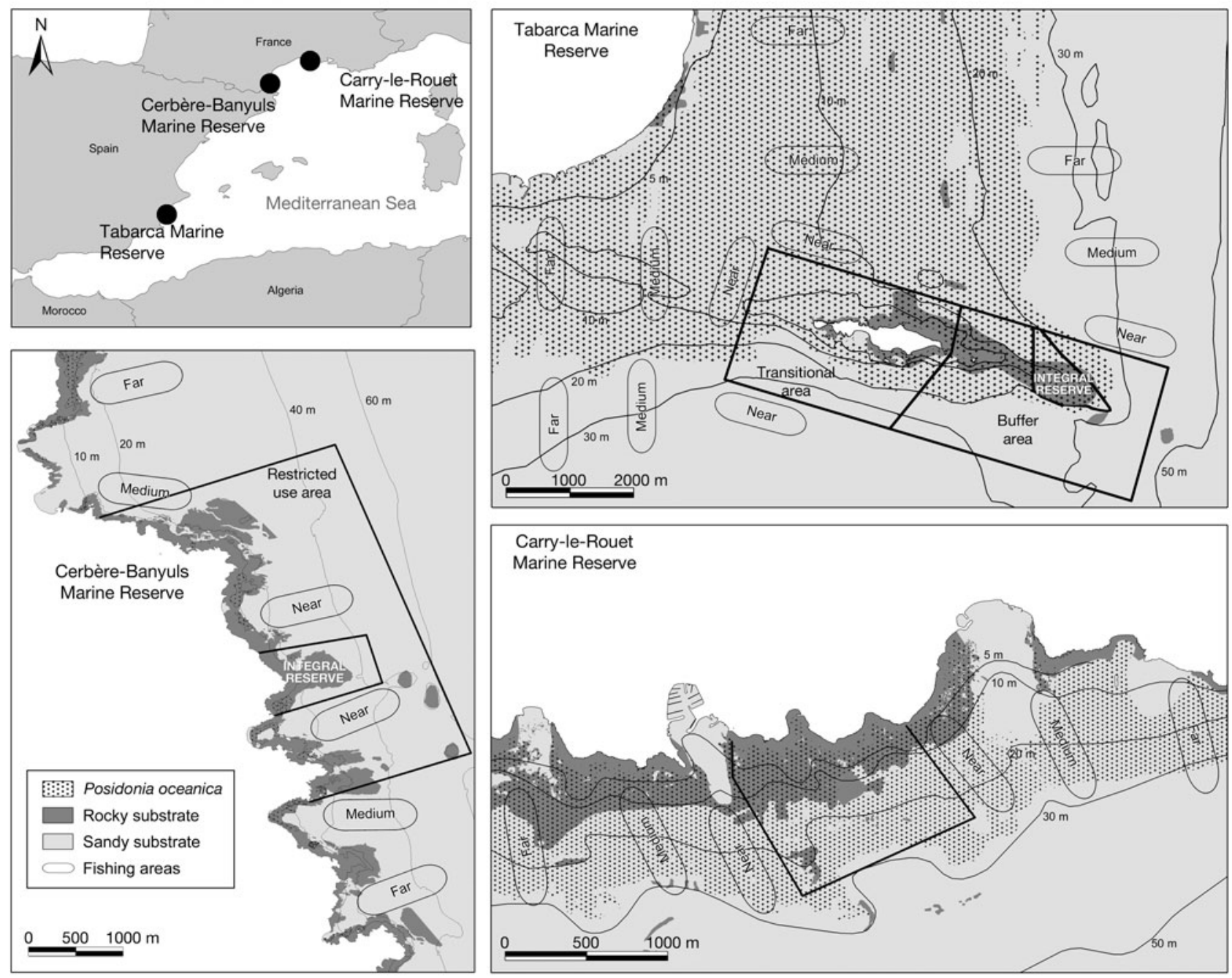

Fig. 1. Tabarca, Cerbère-Banyuls and Carry-le-Rouet Marine Reserve locations; their limits and zonations are included. General habitat characteristics and the areas where the experimental fishing was carried out at each distance are also indicated

92\% higher in Tabarca Marine Reserve (Forcada 2005), 117 \% in Cerbère-Banyuls Marine Reserve (Bell 1983) and $78 \%$ in Carry-le-Rouet Marine Reserve (Harmelin et al. 1995) with reference to fished areas.

In 2 of the MPAs (Tabarca and Carry-le-Rouet), the main habitat, Posidonia oceanica meadows, extends far outside the borders (Fig. 1). Rocky and sandy bottoms are also present in Tabarca. In CerbèreBanyuls Marine Reserve rocky and sandy bottoms are the main habitats, and seagrass only covers about $1 \%$ of the total area.

Traditional fishing grounds distributed around the 3 MPAs are mainly used by the artisanal fleet, and are generally composed of boats $<10 \mathrm{~m}$ long, with small crews of 1 to 3 fishers. The artisanal fishery fleet uses trammel nets, gill nets, long-lines and troll-lines. Recreational fishing, including spear fishing, handlining and angling, also occurs around the MPAs.
Sampling design and data collection. Experimental fishing was used to test the hypothesis that catch is higher near the MPAs (500 $\mathrm{m}$ and closer) and declines at medium (500 to $1000 \mathrm{~m}$ ) and far (2000 to $3000 \mathrm{~m}$ ) distances from the MPAs. We tested for such differences in 2 different habitats: Posidonia oceanica seagrass meadows and sandy bottoms (Fig. 1). The fishing survey on homogeneous seagrass was carried out in Tabarca and Carry-le-Rouet Marine Reserves, at depths of 10 to $25 \mathrm{~m}$. Experimental fishing on sandy bottoms was carried out at $30 \mathrm{~m}$ depth around Tabarca and Cerbère-Banyuls Marine Reserves. Surveys were done in spring, summer and winter, although the summer survey at Cerbère-Banyuls Marine Reserve was suspended due to bad weather conditions. Each MPA was sampled 6 d per season, with six 100 m trammelnet replicates per day at each distance. Nets were set before sunset and recovered just after sunrise. After 
fishing, all captured individuals were identified to species, and total length and wet weight were recorded.

Data analysis. The experimental design was different for each habitat. On Posidonia oceanica meadows the experimental design consisted of 4 factors: Distance (3 levels, fixed), MPA (2 levels, fixed and orthogonal), Season (3 levels, fixed and orthogonal) and Day ( 6 levels, random and nested in the interaction MPA $\times$ Season). Thus, with $\mathrm{n}=6$ trammel nets, there was a total of 648 observations.

On sand, the experimental design consisted of 3 factors: Distance (3 levels, fixed), Season (3 levels in Tabarca Marine Reserve and 2 levels in CerbèreBanyuls Marine Reserve, fixed and orthogonal) and Day (6 levels, random and nested in Season). Therefore, with $n=6$ trammel nets, there was a total of 324 observations for the Tabarca Marine Reserve and 216 for the Cerbère-Banyuls Marine Reserve.

Analysis of variance (ANOVA) was used to test for significant differences in biomass of total catch and of the abundant species (Underwood 1997). When the ANOVA F-test was significant, post hoc analyses were conducted using Student-Newman-Keuls (SNK) multiple comparisons (Underwood 1981). Before analysis, Cochran's test (Cochran 1951) was used to test for homogeneity of variance. When significant heterogeneity was found, the data were transformed by $\sqrt{ }(x+1)$ or $\ln (x+1)$. When transformations did not remove heterogeneity, analyses were performed on the untransformed data, but with the $F$-test $\alpha$-value set at 0.01 , since ANOVA is robust to departures from this assumption, especially when the design is balanced and contains a large number of samples or treatments (Underwood 1997).

\section{RESULTS}

\section{Posidonia oceanica meadows in Tabarca and Carry-le-Rouet Marine Reserves}

In the survey, 6619 individuals of 76 species were captured (Table A1 in Appendix 1, available at www. int-res.com/articles/suppl/m379p197_app.pdf). Total weight of the catch was $1373.5 \mathrm{~kg}$. The most common family was Sparidae, followed by Labridae, with 14 and 12 species, respectively. Although 57 species were found in Tabarca Marine Reserve and 56 in Carryle-Rouet Marine Reserve, the 2 MPAs differed in their catch composition. Twenty of the species caught at Tabarca did not appear at Carry-le-Rouet. In contrast, 19 species were caught exclusively at Carry-le-Rouet.

Despite the large number of species caught in both Tabarca and Carry-le-Rouet Marine Reserves, around $85 \%$ of the catch was represented by 15 species. The most common species of the total catch in both MPAs was Scorpaena porcus. Other species common to both MPAs were Labrus merula, Symphodus tinca and Sepia officinalis. Some species were only common in one MPA - Sciaena umbra and Dentex dentex in Tabarca and Diplodus annularis and Octopus vulgaris in Carry-le-Rouet.

Total mean biomass was greater in Tabarca $(2.59 \pm$ $0.08 \mathrm{~kg}$ per $100 \mathrm{~m}$ of net) than in Carry-le-Rouet (1.65 \pm $0.07 \mathrm{~kg}$ per $100 \mathrm{~m}$ of net). Differences between distances were greater during winter in Tabarca and during summer in Carry-le-Rouet (Fig. 2a,c). Higher catches usually occurred near the borders of both MPAs, but there were exceptions. In spring, total mean biomass was higher far from the border of Tabarca (Fig. 2a). In Carry-le-Rouet, catches were similar at near and far distances in winter (Fig. 2c). With respect to seasonality, only Tabarca showed a clear pattern, with the greater values in winter.

In ANOVAs for catch, the 3-way interaction of Distance, MPA and Season was significant (Table 1). In SNK comparisons, catch was significantly higher near the border in Tabarca during winter and in Carry-leRouet during spring. Moreover, during summer in Carry-le-Rouet, total catch was highest near the reserve.

At the species level, catches of Scorpaena porcus decreased away from the boundaries at both MPAs (Fig. 3a), and the interaction between Distance, MPA and Season was significant (Table 1). SNK test results indicated that far from Tabarca catches were lowest. However in Carry-le-Rouet, higher catches were obtained near the MPA border only in summer $(p<$ 0.01). Labrus merula also had a decreasing trend with distance at both MPAs (Fig. 3b), but catches were only significantly higher close to Tabarca. Furthermore, catches of this species were significantly higher in Tabarca than in Carry-le-Rouet during all seasons $(\mathrm{p}<$ 0.01). Catches of Mullus surmuletus declined with distance in both MPAs, but only in winter (Fig. 3c). However, these differences were significant only in Tabarca, with higher catches near the boundaries $(\mathrm{p}<$ $0.01)$.

Other important species, such as Sciaena umbra (Fig. 4a) and Dentex dentex (Fig. 4b), showed catches decreasing with distance, but only in Tabarca Marine Reserve $(p<0.01)$; these species were rare or absent at the other MPAs. In contrast, decreasing trends with distance of Conger conger (Fig. 4c) and Phycis phycis (Fig. 4d) were observed only in Carry-le-Rouet; catches around Tabarca were low. C. conger was always caught more frequently $(\mathrm{p}<0.05)$ close to Carry-le-Rouet boundaries, while catches of $P$. phycis were significantly higher $(\mathrm{p}<0.01)$ only in winter and spring. 
ANOVA results for Symphodus tinca (Fig. 3d) and Diplodus vulgaris (Fig. 3e) produced a significant interaction between Distance, MPA and Season (Table 1); the SNK multiple comparisons reflected inconsistencies with the primary hypothesis. Catches of $S$. tinca were significantly higher in summer and spring near Carryle-Rouet $(\mathrm{p}<0.05)$ and in winter near Tabarca $(\mathrm{p}<$ $0.05)$; during spring the highest catches were far from Tabarca $(\mathrm{p}<0.01)$. In contrast, $D$. vulgaris catches were not significantly different with distance at Carry-leRouet, even though the trend in winter and spring was of decreasing catches with distance. At Tabarca, the pattern of $D$. vulgaris changed depending on the survey. Biomass was significantly higher near the MPA in summer $(p<0.05)$, but catches were significantly greater far from Tabarca during winter $(p<0.01)$ and at a medium distance during spring $(\mathrm{p}<0.05)$.

The rest of the species analyzed (Diplodus annularis, Diplodus sargus, Muraena helena, Octopus vulgaris, Sepia officinalis and Torpedo marmorata) did not show significant differences in catch among distances, but their catches differed significantly between both MPAs in some or all of the seasons studied (Table 1).

Some catches of species displayed significant seasonality (Table 1). The most clear was for Sepia officinalis, the catches of which were significantly different among all the seasons at both MPAs. Torpedo marmorata also had this seasonality in its catches, but with a different pattern at each MPA. Some species showed significant differences among seasons only in Tabarca Marine Reserve (Labrus merula, Dentex dentex and Sciaena umbra), whereas others showed significant differences only in Carry-le-Rouet Marine Reserve (Diplodus annularis and Octopus vulgaris).

\section{Sandy bottoms in Tabarca Marine Reserve}

During the fishing survey, 2427 individuals of 56 species were caught (Table A2 in Appendix 1, available at www.int-res.com/articles/suppl/m379p197_app.pdf). Total weight catch was $444.2 \mathrm{~kg}$. The most wellrepresented family was Sparidae, with 13 species, and $82 \%$ of the catch was represented by 18 species. Once again Scorpaena porcus was the most abundant species, although sandy bottoms are not their preferred habitat. Scorpaena scrofa, Torpedo marmorata, Sciaena umbra and Myliobatis aquila also represented a high proportion of the total catch (Table A2).

In contrast with the results in Posidonia oceanica meadows, there was no clear trend related to distance over the sand habitat (Fig. 2b). There was, however,
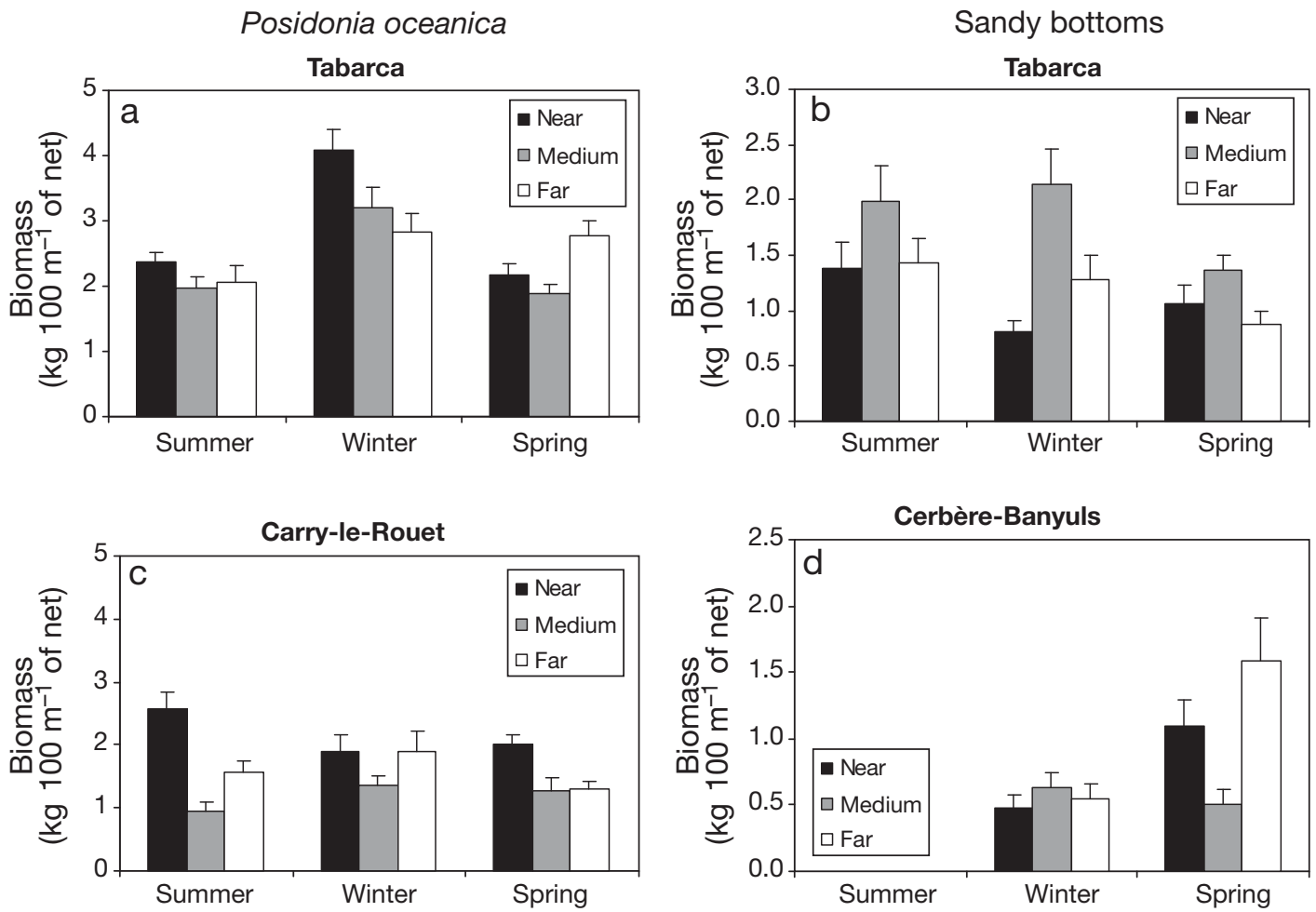

Fig. 2. Trends in total catch of nets fished in $(\mathrm{a}, \mathrm{c})$ Posidonia oceanica seagrass meadows and on $(\mathrm{b}, \mathrm{d})$ sandy bottoms at different distances (see Fig. 1) from the Tabarca, Cerbère-Banyuls and Carry-le-Rouet Marine Reserves during the different surveys. Error bars $=$ standard error 


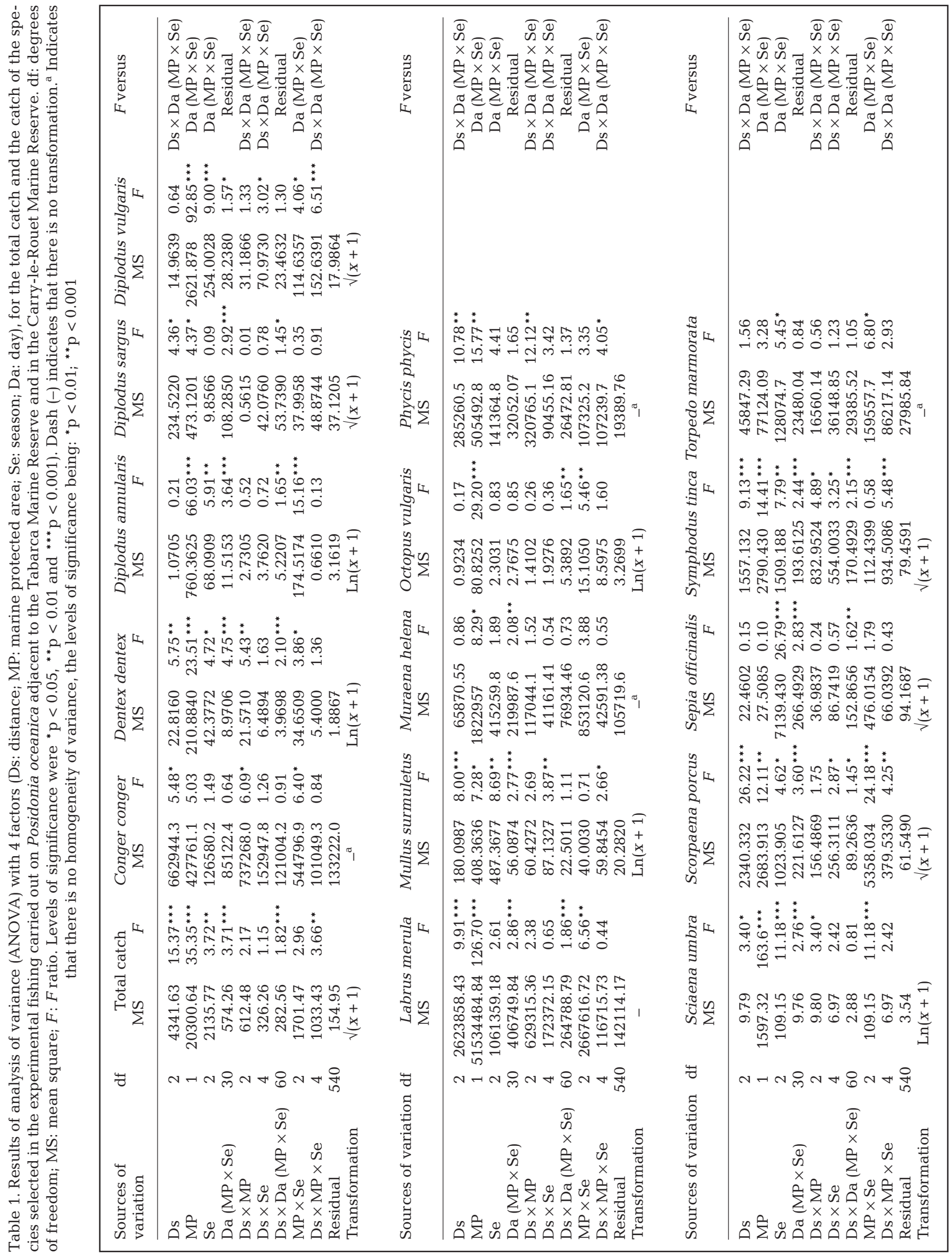




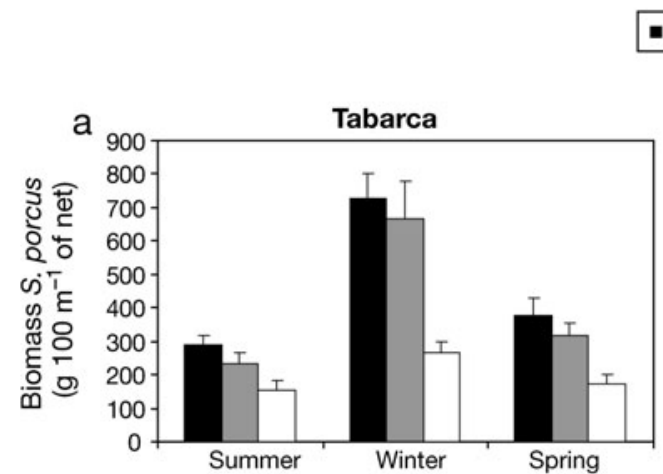

- Near a Medium $\square$ Far
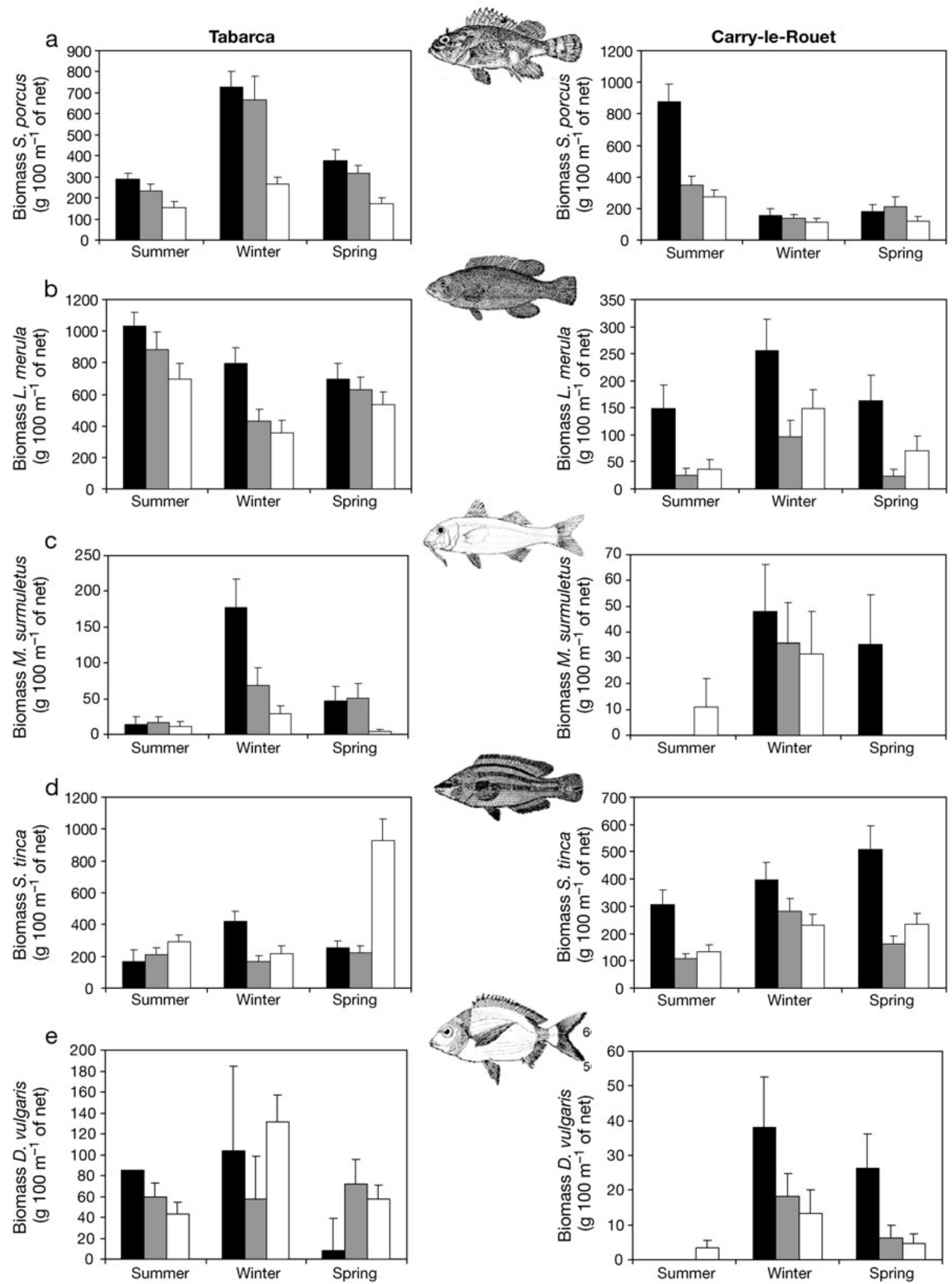

Fig. 3. Trends in catches of: (a) Scorpaena porcus, (b) Labrus merula, (c) Mullus surmuletus, (d) Symphodus tinca and (e) Diplodus vulgaris fished in Posidonia oceanica seagrass meadows at different distances (see Fig. 1) from the Tabarca and Carryle-Rouet Marine Reserves during the 3 surveys. Error bars = standard error 

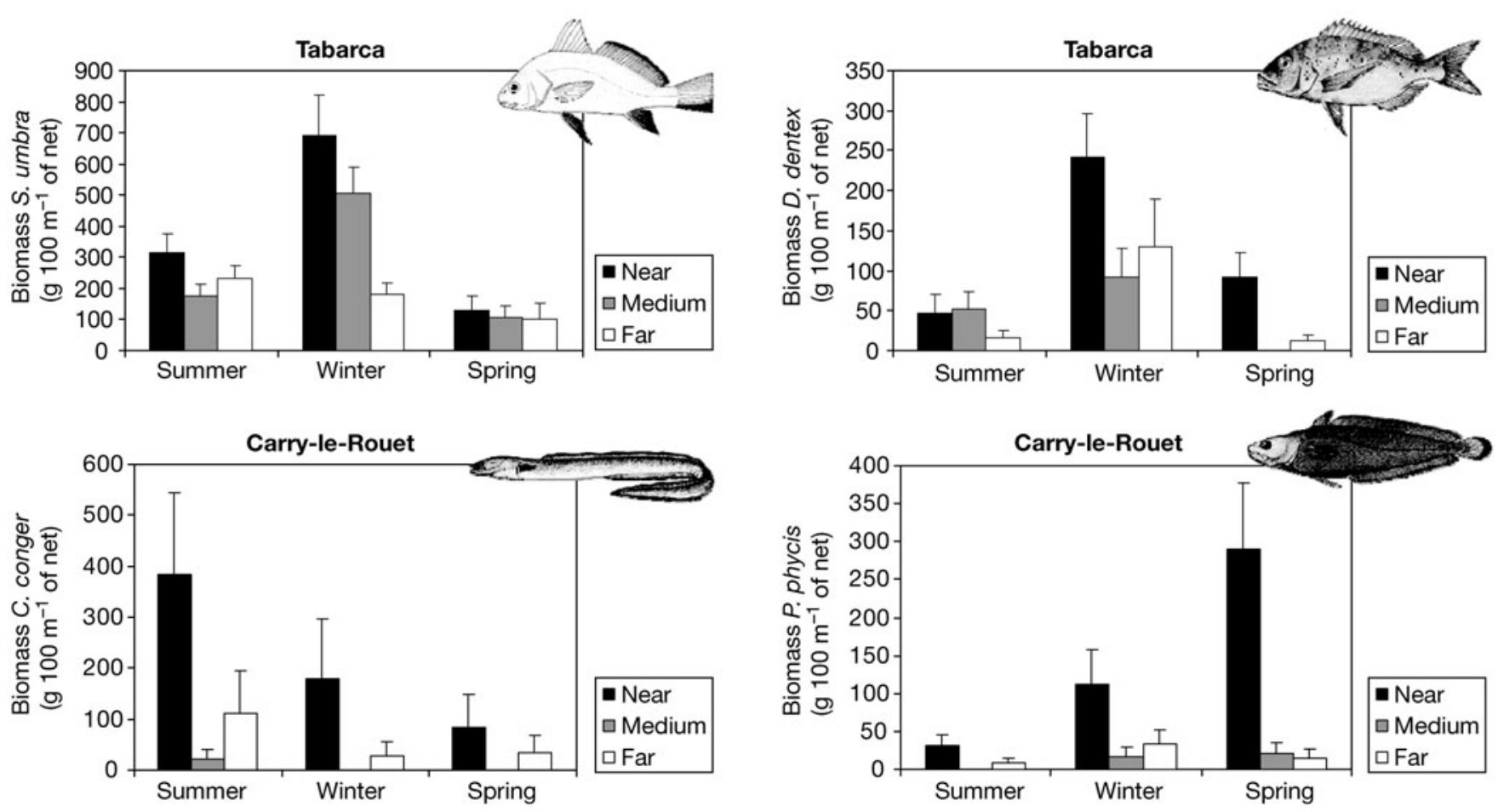

Fig. 4. Trends in catches, at different distances (see Fig. 1) during the 3 surveys, of nets fished in Posidonia oceanica seagrass meadows for: (a) Sciaena umbra and (b) Dentex dentex in the Tabarca Marine Reserve and for: (c) Conger conger and (d) Phycis phycis in the Carry-le-Rouet Marine Reserve. Error bars = standard error

a significant interaction between Distance and Day (Table 2), because significant differences among distances occurred on only 9 of $18 \mathrm{~d}$. Of these, only 2 exhibited the expected trend (significantly higher catches near the boundaries), while the remaining 7 exhibited catches that were significantly higher at intermediate or far distances.

In general, trends in catch at the species level were inconsistent with our main hypothesis, with the highest biomasses existing at the intermediate or far distance. The biomasses of Myliobatis aquila, Octopus vulgaris, Raja spp., Scorpaena scrofa and Uranoscopus scaber were higher in the intermediate distance catches. However, these patterns were only significant (Table 2 ) for the biomasses of M. aquila (Fig. 5a), Raja spp. (Fig. 5b) and U. scaber (Fig. 5c). Moreover, there was a significant interaction between Distance and Season for S. scrofa biomass (Table 2), with significantly higher catches at medium distances in summer and winter.

In addition, other species such as Diplodus vulgaris, Labrus merula, Pagrus pagrus, Sciaena umbra, Sepia officinalis, Spondyliosoma cantharus and Symphodus tinca had the smallest catches close to the Tabarca boundaries. This pattern was only significant for the biomass of $S$. umbra (Fig. 5d) in all seasons ( $<<0.01)$, and of $S$. tinca in summer $(\mathrm{p}<0.05)$. Furthermore, biomasses of $D$. vulgaris, $S$. officinalis and $S$. cantharus showed a significant interaction between Distance and Day (Table 2), with biomasses higher at intermediate or far distances.

Pagellus erythrinus (Fig. 5e), Scorpaena porcus (Fig. 5f), Spicara maena (Fig. 5g) and Torpedo marmorata (Fig. 5h) displayed a decreasing trend with distance from Tabarca in at least 2 seasons. However, none of these were significant by Distance (Table 2). The interaction between Distance and Day was only significant for $P$. erythrinus and $S$. maena. Biomass was higher for $P$. erythrinus near the MPA boundary on 3 of the $4 \mathrm{~d}$ when significant differences occurred, whereas biomass was higher for $S$. maena near the MPA boundary on 2 of the $3 \mathrm{~d}$ when there were significant differences.

In surveys in Posidonia oceanica meadows, some species catches showed significant seasonality: catches of Torpedo marmorata and Sciaena umbra were significantly greater in winter, whereas the catches of Sepia officinalis were highest in spring (Table 2).

\section{Sandy bottoms in Cerbère-Banyuls Marine Reserve}

A total of 537 individuals of 42 species were caught (Table A2). Total weight of the catch was $174.1 \mathrm{~kg}$. The most well-represented family was Sparidae, with 10 species. Only 12 species represented around $85 \%$ of 


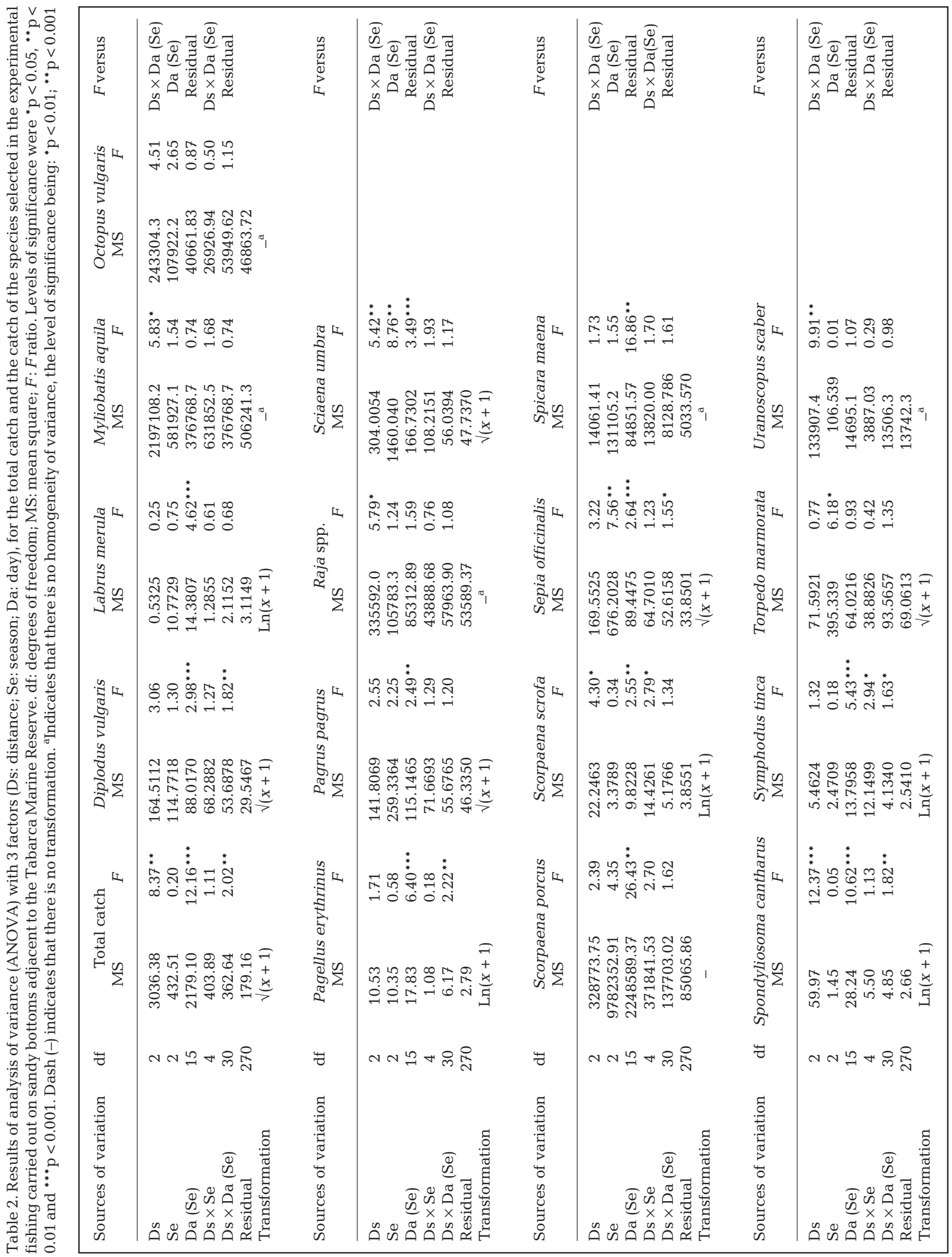


the catches, with the main species being Phycis phycis and Pagellus acarne. Other important species in the total catch were Scorpaena scrofa, Scorpaena porcus and Sepia officinalis.

As with the results for sandy bottoms in Tabarca, there was no clear trend with distance in total catch (Fig. 2d), though there was a significant interaction between Distance and Day (Table 3). On only 2 of the 12 sampling days were there significant differences among distances. Season was periodically important (Table 3); total biomass was significantly greater in spring than in winter.
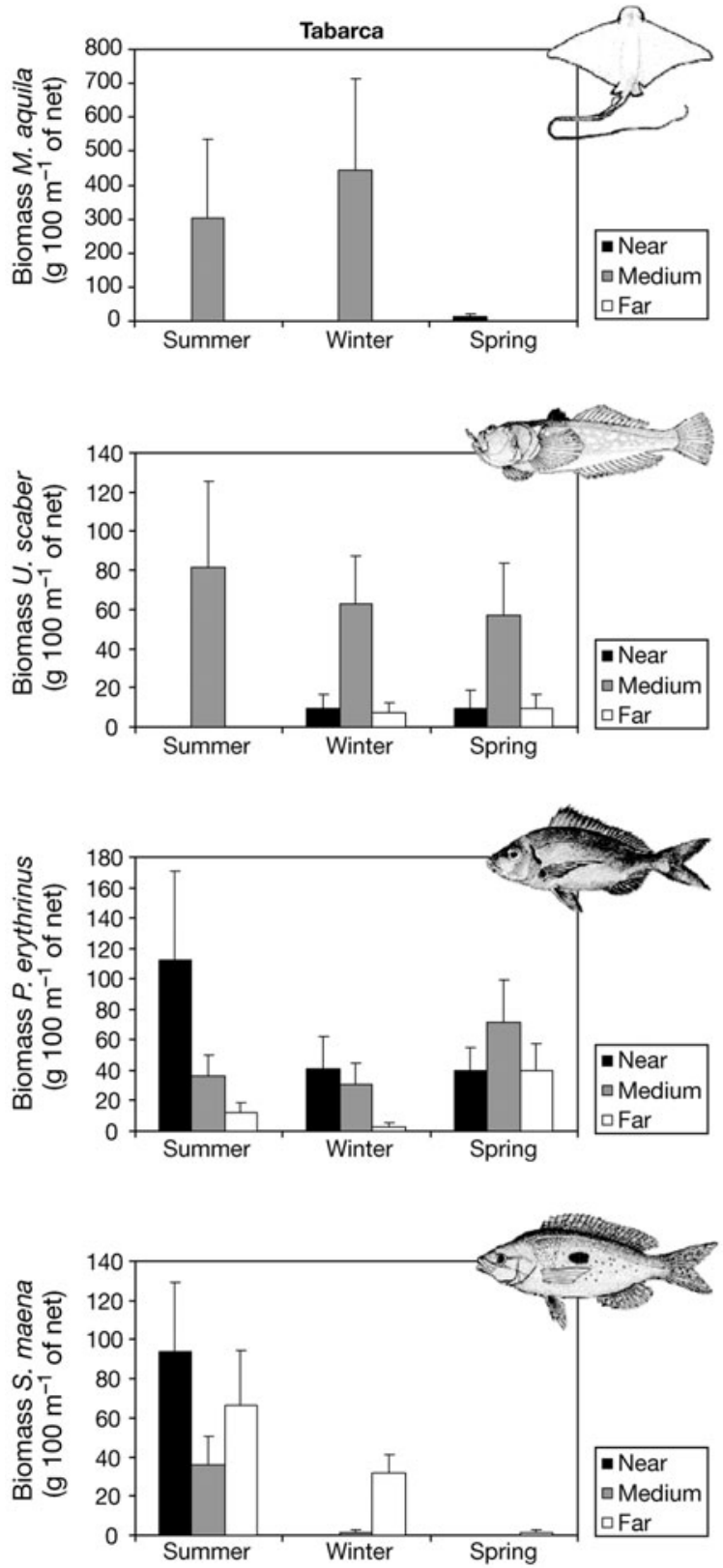

At the species level, catches of Pagellus acarne (Fig. 6a) and Palinurus elephas (Fig. 6b) decreased with distance from the MPA borders. However, only the interaction between Distance and Day was significant for the biomass of $P$. acarne (Table 3). There were $3 \mathrm{~d}$ with significantly higher catches close to the MPA, in contrast to $1 \mathrm{~d}$ with a significantly different trend. Additionally, there were decreasing trends with distance of Mullus surmuletus (Fig. 6c), Sepia officinalis (Fig. 6d) and Uranoscopus scaber (Fig. 6e), but only in one season.
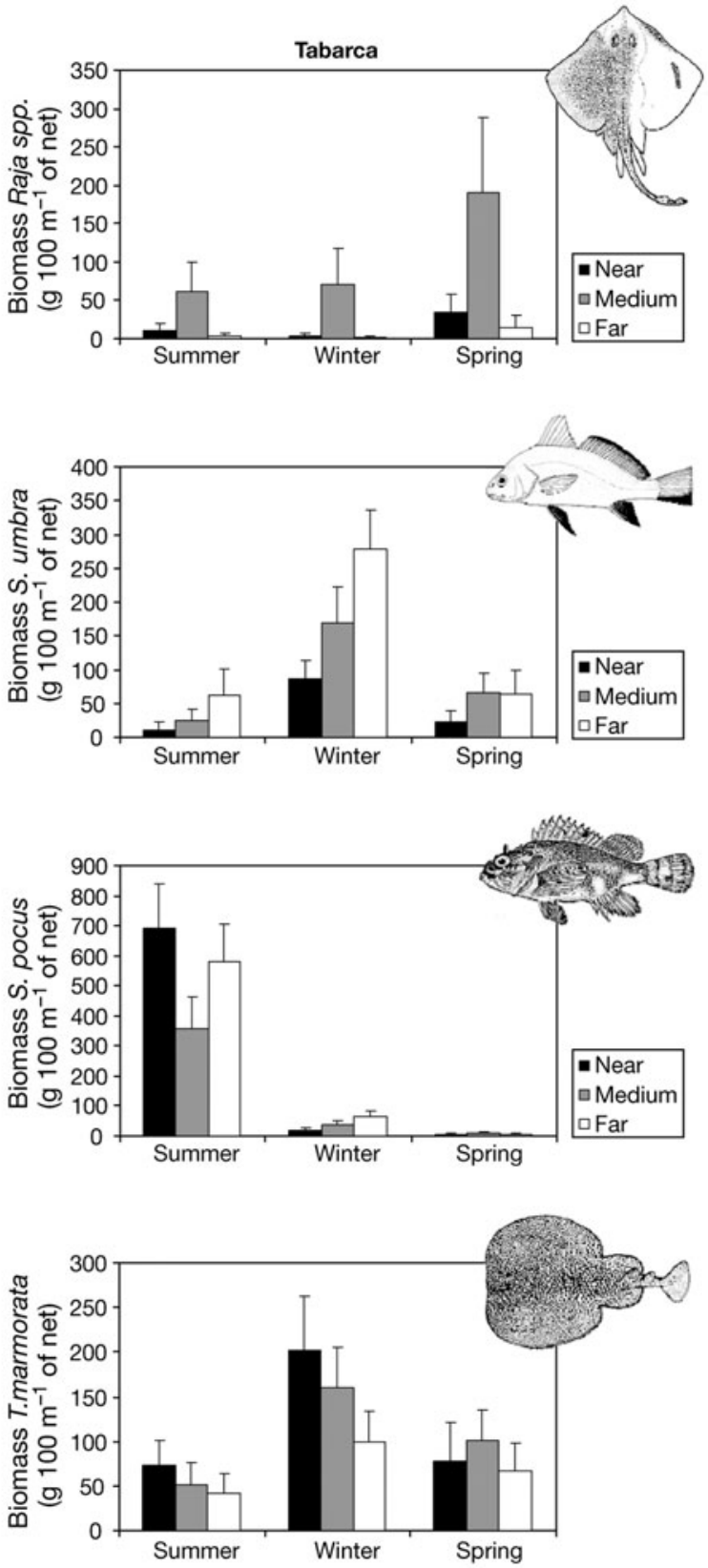

Fig. 5. Trends in catches of: (a) Myliobatis aquila, (b) Raja spp., (c) Uranoscopus scaber, (d) Sciaena umbra, (e) Pagellus erythrinus, (f) Scorpaena porcus, (g) Spicara maena and (h) Torpedo marmorata fished on sandy bottoms at different distances (see Fig. 1) from the Tabarca Marine Reserve during the 3 surveys. Error bars = standard error 


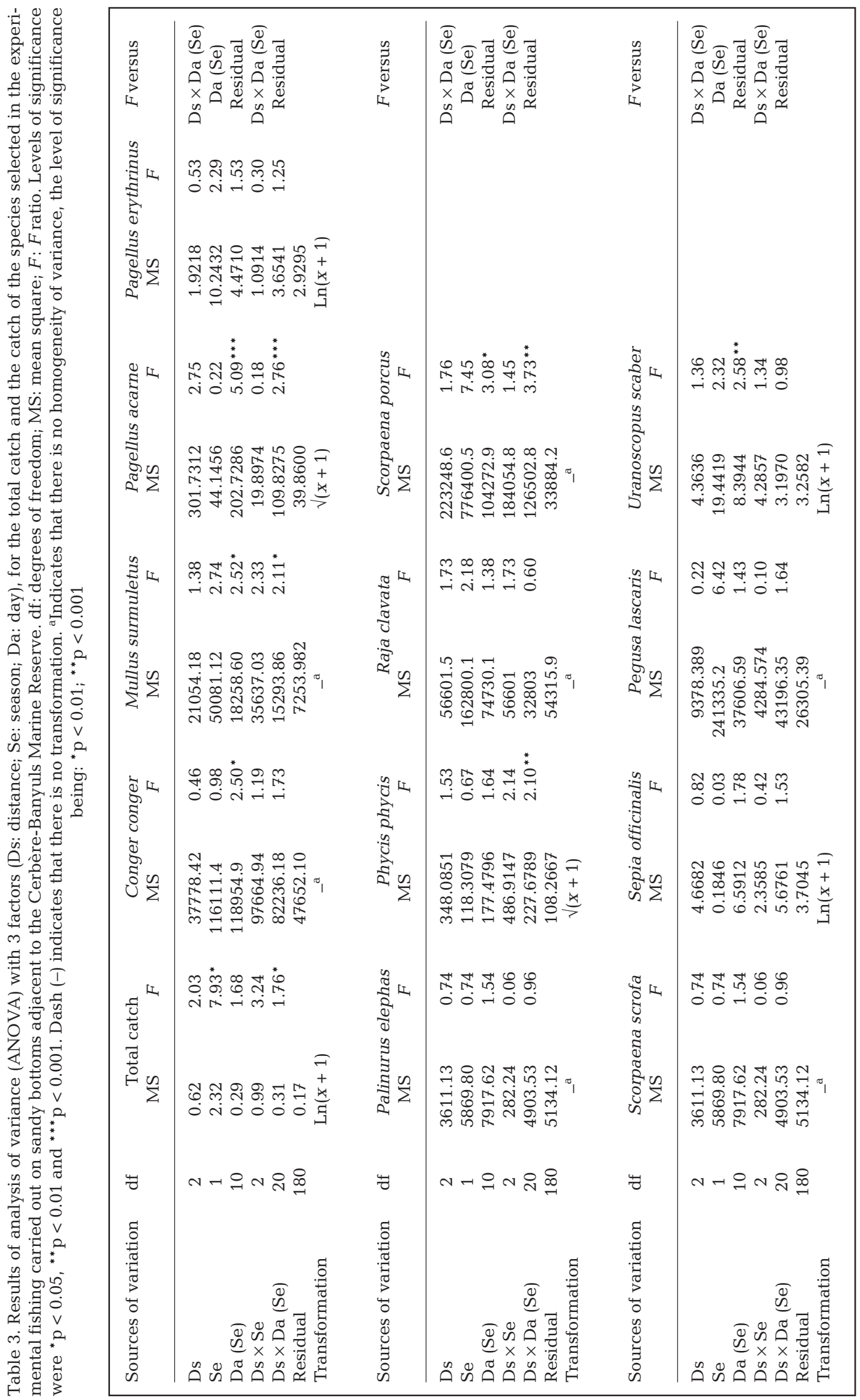



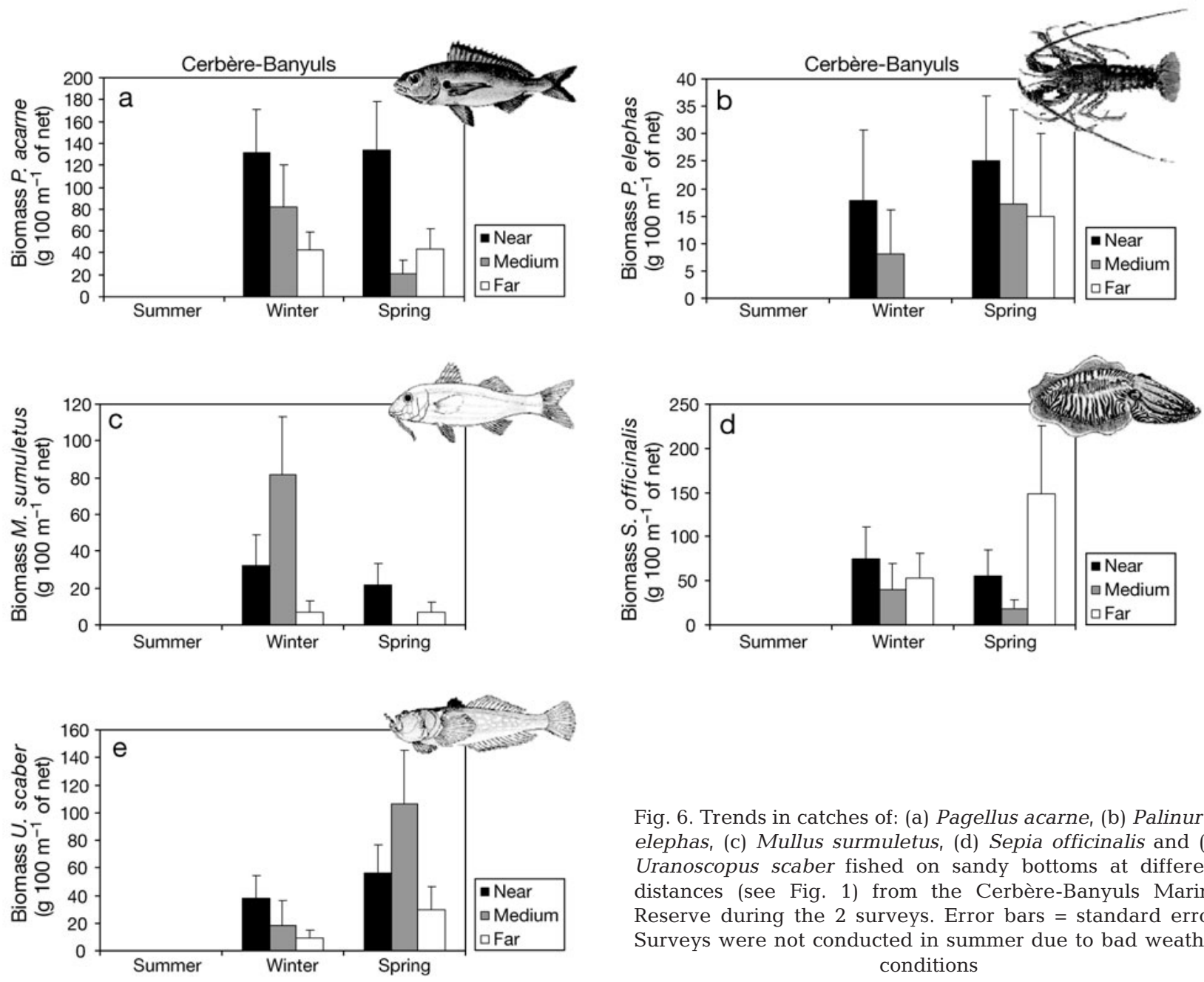

Fig. 6. Trends in catches of: (a) Pagellus acarne, (b) Palinurus elephas, (c) Mullus surmuletus, (d) Sepia officinalis and (e) Uranoscopus scaber fished on sandy bottoms at different distances (see Fig. 1) from the Cerbère-Banyuls Marine Reserve during the 2 surveys. Error bars = standard error. Surveys were not conducted in summer due to bad weather conditions

In general, trends in the catch of Pagellus erythrinus, Phycis phycis, Scorpaena scrofa and Pegusa lascaris were inconsistent with our hypothesis, with higher catches at the intermediate or far distances. Moreover, species such as Conger conger, Raja clavata and Scorpaena porcus were absent at some of the distances or in some of the seasons, complicating the identification of a general trend. P. lascaris was the only species that showed significant differences between seasons (Table 3); catches in winter were significantly higher than in spring.

\section{DISCUSSION}

Fisheries spillover was detected in some surveys in the Posidonia oceanica meadows near the MPA boundaries of both Tabarca and Carry-le-Rouet Marine Reserves. However, differences between surveys indicated that spillover did not occur consistently. This inconsistency may be related to differences in

abundance (Harmelin et al. 1995) or catchability (Maunder et al. 2006) of the species due to seasonal variation.

Species that showed a significant response to protection were those typical of Posidonia oceanica meadows or shallow rocky bottoms, which are the main protected habitats at both MPAs (Conger conger, Dentex dentex, Labrus merula, Mullus surmuletus, Phycis phycis, Sciaena umbra, Scorpaena porcus and Symphodus tinca). Other species, like Diplodus spp., Muraena helena, or cephalopods, did not present clear trends in spite of their high contribution to the catches.

Some of the species that responded to protection with higher catches near the border, such as Dentex dentex, Mullus surmuletus, Phycis phycis, Sciaena umbra and Scorpaena porcus, are important target species of artisanal fisheries (García-Rodríguez et al. 2006, Forcada 2007, Goñi et al. 2008). Moreover, these species represent the highest proportion of the catch and the greatest income for artisanal fisheries (GarcíaRodríguez et al. 2006, Forcada 2007, Goñi et al. 2008). 
Therefore, export of fish from the MPAs, even if it is limited, should provide economic benefits to artisanal fleets.

Although fisheries enhancement was detected very close to MPA borders in general, there were some differences between the Tabarca and Carry-le-Rouet Marine Reserves. They are located in different biogeographical sectors (Garibaldi \& Caddy 1998, Bianchi \& Morri 2000), and one of the most important differences is that of sea temperature, which ranges at the surface from 13 to $27^{\circ} \mathrm{C}$ in Tabarca and from 12 to $24^{\circ} \mathrm{C}$ in Carry-le-Rouet. This accounts for the higher abundance at Tabarca of certain species typical of warmer waters (Sciaena umbra and Dentex dentex), which are rare in the northern Mediterranean (Harmelin 1991, Ramos-Esplá \& Bayle 1991, Francour et al. 1994).

The other difference between the MPAs is that at Carry-le-Rouet the increase of the catches was only detected near the boundaries, whereas at Tabarca some effects, like the increase of Scorpaena porcus and Sciaena umbra catches, reached an intermediate distance, only declining at the fishing ground furthest from the MPA. This may be interpreted in relation to the size of each MPA. Carry-le-Rouet is a very small reserve (85 ha) that has a very limited influence over the surrounding fished area, while Tabarca is a larger one (1400 ha) that seems to have a wider exportation effect. The effect of protection of juveniles and adults is edge dependent. The probability of fish leaving a given reserve, and consequently increasing their vulnerability, will decrease in proportion to the increase in size of the MPA (Kramer \& Chapman 1999, Chapman \& Kramer 2000, Roberts et al. 2001b). Therefore, small MPAs may not support populations efficiently (Edgar \& Barrett 1999), especially for mobile species that often cross reserve boundaries. However, small MPAs can have an important protective role in the case of sedentary species or if the the reserves are situated at crucial locations, such as aggregation sites for spawning (Beets \& Friedlander 1999). There are no upper limits on reserve size that are relevant to conservation goals, but to achieve an export of fishable stocks they should not be too large (Roberts et al. 2003). If reserves are made too large, then spillover to fisheries will be prevented, while making reserves too small will yield no benefits. It is difficult to be precise about what constitutes 'too large' because it depends on the mobility of the species involved and local oceanographic conditions (Roberts et al. 2003). To determine what reserve size is too small more empirical study is required (Edgar \& Barrett 1999, Halpern 2003, Guidetti et al. 2005). From the results obtained, Tabarca Marine Reserve and Carry-le-Rouet Marine Reserve seem large enough to promote population recovery, and yet are small enough to permit some spillover for the benefit of local fisheries. Even the small MPA appears capable of generating increases in catches near its boundaries; the larger one shows the same effects, but proportional to its size. For that reason, the absolute impacts of small and large reserves will be very different. Although the observations at each MPA size were not replicated, these results offer some empirical evidence suggesting that the amount of protected area is important.

In contrast, there was no clear trend in catches on sand in Tabarca and Cerbère-Banyuls Marine Reserves. Only a few of the surveys showed higher catches near the boundaries, and only 2 of the species, Pagellus acarne and Palinurus elephas, evidenced decreasing trends with distance in the Cerbère-Banyuls Marine Reserve, but neither of these was significant.

It appears that biomass is exported through Posidonia oceanica meadows (at least for some species and seasons), while little export occurs through sandy bottoms. At both Tabarca and Carry-le-Rouet Marine Reserves, the main habitat, P. oceanica meadow, extends outside the borders. Rocky and sandy bottoms are also present in Tabarca Marine Reserve, but are very limited, $\sim 10$ and $\sim 20 \%$, respectively, of the surface protected. Something similar occurs in CerbèreBanyuls Marine Reserve, which protects mainly rocky bottoms, and sandy bottoms start just near the MPA boundaries.

The types and qualities of habitats, both inside and outside the reserve, determine how a species responds to reserve protection (Agardy 1995, Nilsson 1998). It is desirable that reserves protect habitats where species feed and reproduce and where they spend a considerable portion of time (Kramer \& Chapman 1999). In this sense, habitats can act as surrogates for species in reserve planning, simplifying the task of deciding what to protect (Roberts et al. 2001b). On the other hand, the relative mobility of some species (Chapman \& Kramer 2000) suggests that movement across the boundary would be much greater if the boundary divides an area of continuous habitat. It has been pointed out (Roberts 2000) that habitat continuity through MPA boundaries is important for biomass export to open fished areas, and our results confirm this assessment.

Although we found that the spatial scale of the spillover-induced density gradient is very localized, it is, nevertheless, sufficient to provide local benefits to artisanal fisheries (through juvenile and adult spillover) and possibly more regional benefits (through greater larval export). We conclude that spillover effects are not a universal consequence of marine protected areas in temperate waters, and that they are related to the distribution of habitat inside and around the reserve. 
Acknowledgements. We very much appreciated the help received from A. Delauney, K. Kawahara, M. Capoulade and B. Luna during field data collection. We acknowledge the friendly cooperation of the fishermen of Tabarca, Carry-leRouet and Cerbère-Banyuls. This research was financed by UE-DG Fisheries through the project BIOMEX (QLRT-200100891), WP5. A.F. was supported by an FPI grant from the Generalitat Valenciana (CTBPRB/2003/146). We thank the FAO for providing species drawings for Figs. 3, 4, $5 \& 6$. We also thank the anonymous reviewers and the editor for their useful comments on the manuscript.

\section{LITERATURE CITED}

Abesamis RA, Russ GR (2005) Density-dependent spillover from a marine reserve: long-term evidence. Ecol Appl 15: 1798-1812

Agardy TE (1995) The science of conservation in the coastal zone: new insight on how to design, implement, and monitor marine protected areas. A marine conservation and development report. IUCN, Gland

- Beets J, Friedlander A (1999) Evaluation of a conservation strategy: a spawning aggregation closure for red hind, Epinephelus guttatus, in the US Virgin Islands. Environ Biol Fishes 55:91-98

Bell JD (1983) Effects of depth and marine reserve fishing restrictions on the structure of a rocky reef fish assemblage in the north-western Mediterranean Sea. J Appl Ecol 20:357-369

Bianchi CN, Morri C (2000) Marine biodiversity of the Mediterranean Sea: situation, problems and prospects for future research. Mar Pollut Bull 40:367-376

Bohnsack JA (1990) The potential of marine fishery reserves for reef fish management in the US southern Atlantic. NOAA Tech Memo NMFS-SEFC-261, National Oceanic and Atmospheric Administration, Miami, FL

Castilla JC (2000) Roles of experimental marine ecology in coastal management and conservation. J Exp Mar Biol Ecol 250:3-21

> Chapman MR, Kramer DL (2000) Movements of fishes within and among fringing coral reefs in Barbados. Environ Biol Fishes 57:11-24

> Cocheret de la Moriniere E, Pollux BJA, Nagelkerken I, van der Velde G (2002) Post-settlement life cycle migration patterns and habitat preference of coral reef fish that use seagrass and mangrove habitats as nurseries. Estuar Coast Shelf Sci 55:309-321

Cochran WG (1951) Testing a linear relation among variances. Biometrics 7:17-32

Edgar GJ, Barrett NS (1999) Effects of the declaration of marine reserves on Tasmanian reef fishes, invertebrates and plants. J Exp Mar Biol Ecol 242:107-144

Forcada A (2005) Ictiofauna en reservas marinas: influencia de la estructura del hábitat, efecto de la protección y tamaño del área protegida. Instituto Alicantino de Cultura Juan Gil-Albert, Publicaciones de la Diputación de Alicante, Alicante

Forcada A (2007) Evaluación de las Áreas Marinas Protegidas y su efecto en pesquerías artesanales del Mediterráneo Occidental. PhD thesis, University of Alicante, Alicante

> Francour P, Boudouresque CF, Harmelin-Vivien M, Harmelin JG, Quignard JP (1994) Are the Mediterranean waters becoming warmer? Information from biological indicators. Mar Pollut Bull 28:523-526

> Galal N, Ormond RFG, Hassan O (2002) Effect of a network of no-take reserves in increasing catch per unit effort and stocks of exploited reef fish at Nabq, South Sinai, Egypt. Mar Freshw Res 53:199-205

García-Rodríguez MA, Fernández M, Esteban A (2006) Characterisation, analysis and catch rates of the small-scale fisheries of the Alicante Gulf (SE Spain) over a 10 years time series. Fish Res 77:226-238

Garibaldi L, Caddy JF (1998) Biogeographic characterization of Mediterranean and Black Seas faunal provinces using GIS procedures - a need for concerted international action. Ocean Coast Manag 39:211-227

> Gell FR, Roberts CM (2003) Benefits beyond boundaries: the fishery effects of marine reserves. Trends Ecol Evol 18: $448-455$

> Goñi R, Quetglas A, Reñones O (2006) Spillover of spiny lobsters Palinurus elephas from a marine reserve to an adjoining fishery. Mar Ecol Prog Ser 308:207-219

Goñi R, Adlerstein S, Alvarez-Berastegui D, Forcada A and others (2008) Spillover from six western Mediterranean marine protected areas: evidence from artisanal fisheries. Mar Ecol Prog Ser 366:159-174

Guidetti P, Verginella L, Viva C, Odorico R, Boero F (2005) Protection effects on fish assemblages, and comparison of two visual-census techniques in shallow artificial rocky habitats in the northern Adriatic Sea. J Mar Biol Assoc UK 85:247-255

Halpern BS (2003) The impact of marine reserves: Do reserves work and does size matter? Ecol Appl 13:117-137

Harmelin JG (1991) Statut du corb (Sciaena umbra) en Méditerranée. In: Boudouresque CF, Avon M, Gravez V (eds) Les espèces marines à protéger en Méditerranée. GIS Posidonie Publications, Marseille, p 219-227

> Harmelin JG, Bachet F, García F (1995) Mediterranean marine reserves: fish indices as tests of protection efficiency. PSZN I: Mar Ecol 16:233-250

Hilborn R, Stokes K, Maguire JJ, Smith T and others (2004) When can marine reserves improve fisheries management? Ocean Coast Manag 47:197-205

Kaunda-Arara B, Rose GA (2004) Effects of marine reef National Parks on fishery CPUE in coastal Kenya. Biol Conserv 118:1-13

Kramer DL, Chapman MR (1999) Implications of fish home range size and relocation for marine reserve function. Environ Biol Fishes 55:65-79

Maunder MN, Sibert JR, Fonteneau A, Hampton J, Kleiber P, Harley SJ (2006) Interpreting catch per unit effort data to assess the status of individual stocks and communities. ICES J Mar Sci 63:1373-1385

> McClanahan TR, Kaunda-Arara B (1996) Fishery recovery in a coral-reef marine park and its effect on the adjacent fishery. Conserv Biol 10:1187-1199

McClanahan TR, Mangi S (2000) Spillover of exploitable fishes from a marine park and its effect on the adjacent fishery. Ecol Appl 10:1792-1805

Murawski SA, Brown R, Lai HL, Rago PJ, Hendrickson L (2000) Large-scale closed areas as a fishery-management tool in temperate marine systems: the Georges Bank experience. Bull Mar Sci 66:775-798

Murawski SA, Wigley SE, Fogarty MJ, Rago PJ, Mountain DG (2005) Effort distribution and catch patterns adjacent to temperate MPAs. ICES J Mar Sci 62:1150-1167

> Nagelkerken I, van der Velde G (2002) Do non-estuarine mangroves harbour higher densities of juvenile fish than adjacent shallow-water and coral reef habitats in Curaçao (Netherlands Antilles)? Mar Ecol Prog Ser 245:191-204

Nilsson P (1998) Criteria for the selection of marine protected areas. Report 4834, Swedish Environmental Protection Agency, Stockholm 
Pauly D, Christensen V, Guénette S, Pitcher TJ and others (2002) Towards sustainability in world fisheries. Nature 418:689-695

Rakitin A, Kramer DL (1996) Effect of a marine reserve on the distribution of coral reef fishes in Barbados. Mar Ecol Prog Ser 131:97-113

Ramos-Esplá AA, Bayle J (1991) Estatuto del Dentex dentex (Linneaus, 1758) en el Meiterráneo. In: Boudouresque CF, Avon M, Gravez V (eds) Les espèces marines à protéger en Méditerranée. GIS Posidonie Publications, Marseille, p $237-244$

Ramos-Esplá AA, Valle-Pérez C, Bayle-Sempere JT, SánchezLizaso JL (2004) Áreas Marinas Protegidas como herramientas de Gestión Pesquera en el Mediterráneo (Área COPEMED). Serie Informes y Estudios COPEMED No. 11, Proyecto FAO-COPEMED, Madrid

Roberts CM (2000) Selecting marine reserve locations: optimality versus opportunism. Bull Mar Sci 66:581-592

Roberts CM, Bohnsack JA, Gell F, Hawkins JP, Goodridge R (2001a) Effects of marine reserves on adjacent fisheries. Science 294:1920-1923

Roberts CM, Halpern BS, Palumbi SR, Warner RR (2001b) Reserve networks. Why small, isolated protected areas are not enough. Biol Conserv Pract 2:10-17

Roberts CM, Branch G, Bustamante RH, Castilla JC and others (2003) Applications of ecological criteria in selecting marine reserves and developing reserve networks. Ecol Appl 13:215-228

Rowley RJ (1994) Marine reserves in fisheries management. Aquat Conserv: Mar Freshw Ecosyst 4:233-254

Russ GR, Alcala AC (1996) Do marine reserves export adult

Editorial responsibility: Romuald Lipcius,

Gloucester Point, Virginia, USA fish biomass? Evidence from Apo Island, central Philippines. Mar Ecol Prog Ser 132:1-9

Russ GR, Alcala AC, Maypa AP (2003) Spillover from marine reserves: the case of Naso vlamingii at Apo Island, the Philippines. Mar Ecol Prog Ser 264:15-20

Sale PF, Cowen RK, Danilowicz BS, Jones GP and others (2005) Critical science gaps impede use of no-take fishery reserves. Trends Ecol Evol 20:74-80

Sánchez-Lizaso JL, Goñi R, Reñones O, García Chartón JA and others (2000) Density dependence in marine protected populations: a review. Environ Conserv 27:114-158

Tremain DM, Harnden CW, Adams DH (2004) Multidirectional movements of sportfish species between an estuarine no-take zone and surrounding waters of the Indian River Lagoon, Florida. Fish Bull (Wash DC) 102:533-544

Underwood AJ (1981) Techniques of analysis of variance in experimental marine biology and ecology. Oceanogr Mar Biol Annu Rev 19:513-605

Underwood AJ (1997) Experiments in ecology: their logical design and interpretation using analysis of variance. Cambridge University Press, Cambridge

Wiens JA, Stenseth NC, Van Horne B, Ims RA (1993) Ecological mechanisms and landscape ecology. Oikos 66: 369-380

Willis TJ, Millar RB, Babcock RC, Tolimiery N (2003) Burdens of evidence and the benefits of marine reserves: Putting Descartes before des (sic) horse? Environ Conserv 30: 97-103

Worm B, Barbier EB, Beaumont N, Duffi E and others (2006) Impacts of bbiodiversity loss on ocean ecosystem services. Science 314:787-790

Submitted: November 23, 2007; Accepted: December 16, 2008 Proofs received from author(s): March 13, 2009 